\title{
Metalinguística e desempenho em leitura e escrita
}

\author{
Guimarães, S. R. K. (2005). Aprendizagem da leitura e da escrita: o papel das habilidades \\ metalingüísticas. $I^{a}$ ed. SP: Vetor, 257 p.
}

A aprendizagem da leitura e da escrita tem sido considerada, nos dias atuais, foco de reflexão para muitos educadores. Sabe-se que ainda não há um consenso por parte da comunidade científica para esclarecer os fatores que levam à manifestação das dificuldades de aprendizagem em leitura e escrita. $O$ livro aqui resenhado apresenta um estudo prático sobre as habilidades metalingüísticas e sua relação com a aprendizagem da leitura e da escrita e problemas fonológicos.

O primeiro capítulo está subdividido em sete tópicos cujo tema básico é a Dificuldade de Aprendizagem da Leitura e da Escrita (DLE). Iniciase por uma abordagem histórica da concepção da DLE, sua conceituação mais recente e avança apresentando estudos que relacionam a consciência fonológica e consciência sintática com a aprendizagem da leitura e da escrita associada às habilidades metalinguísticas. Destaque é dado aos problemas presentes durante a aquisição da leitura e da escrita, considerando-se a teoria do processamento da informação. Ao final de cada subtópico há um pequeno resumo sobre $o$ assunto tratado, propiciando ao leitor um entendimento global. Como a autora apresenta diversos aspectos relacionados ao assunto, este serve também como referência sobre os temas específicos, possibilitando um estudo mais aprofundado na área.

Investigar a relação entre o nível de habilidades metalingüísticas e as diferenças de desempenho na leitura e na escrita é o objetivo de um estudo realizado pela autora que é descrito a partir do segundo capítulo. É apresentada detalhadamente a metodologia com os tipos de instrumentos utilizados, numa linguagem que possibilita ao leitor conhecer e compreender os procedimentos de pesquisa utilizados. Os resultados encontrados referem-se tanto à caracterização dos participantes de $\mathrm{I}^{\mathrm{a}}$ a $4^{\mathrm{a}}$ série do ensino fundamental quanto à aquisição da leitura e escrita quanto sua relação com consciência fonológica e habilidades metalinguísticas. A discussão que é necessário fazer intervenções nestes alunos e

O último capítulo intitulado conclusões e considerações finais retomam de forma sintética todo estudo realizado, são descritos o conteúdo dos capítulos e algumas implicações educacionais do presente trabalho. Dentre estas, a autora sugere que sejam desenvolvidos programas de intervenção que privilegiem o desenvolvimento da consciência fonológica, garantindo uma aprendizagem eficaz e o sucesso dos alunos.

As referencias bibliográficas são a grande maioria estrangeiras e provenientes de periódicos científicos. Há uma bibliografia complementar indicada aos leitores e pesquisadores interessados sobre o tema.

Adriana Ferreira Nicolau Pedagoga 